\title{
DISPUTAS POR CHÃOS DE TERRA: EXPANSÁO MERCANTIL E SEU IMPACTO SOBRE A ESTRUTURA FUNDIÁRIA DA CIDADE DE SÃO PAULO (1765-1848)
}

\author{
Denise A. Soares de Moura \\ Professora da Faculdade de Ciências Humanas e Sociais da Universidade \\ Estadual Paulista "Julio de Mesquita Filho", campus de Franca.
}

\begin{abstract}
Resumo
Este artigo trata da administração municipal e a terra urbana no Império Português entre a segunda metade do século XVIII e as primeiras décadas do século XIX. A ideia central é a de que a política do Império de estímulo ao comércio colonial e a maior liberalização do comércio desde a transferência da família real para o Rio de Janeiro incentivaram os conflitos de terra em cidades-entreposto como São Paulo.
\end{abstract}

\section{Pallavras-chave}

administração municipal • terra urbana • comércio colonial.

Correspondência

Faculdade de Ciências Humanas e Sociais /UNESP

Avenida Eufrázia Monteiro Petráglia, n. 900

14409-160 - Jardim Petráglia - Franca - São Paulo

E-mail:dmsoa1@yahoo.com.br

* Este texto é uma versão bastante modificada e mais desenvolvida de uma comunicação de pesquisa apresentada no XV Congresso da AHILA, no simpósio Temático Independências, transformações da terra e revoltas na América Latina (1808-150), coordenado pela profa. Vera Lucia Amaral Ferlini e José Tengarinha e ocorrido em Leiden, Holanda, em agosto de 2008. Devo à FAPESP e ao $\mathrm{CNPq}$, em certos momentos, a concessão de recursos que deram condições para a realização da pesquisa empírica e dos estudos que fundamentam as idéias aqui apresentadas. 


\title{
DISPUTED BY "CHÃOS DE TERRA": EXPANSION AND ITS IMPACT ABOUT THE LAND OF THE SÃO PAULO CITY $(1765-1848)^{*}$
}

\author{
Denise A. Soares de Moura \\ Professor at Faculdade de Ciências Humanas e Sociais of the Universidade \\ Estadual Paulista "Julio de Mesquita Filho", Franca campus.
}

\section{Abstract}

This article treats of municipal administration and the urban land in Portuguese Empire among in the second mid eighteeth century and the first decades of ninetheeth century. The central ideal is that the Empire's policy of stimulation of colonial commerce and the more liberalization of commerce since the change of royal family for Rio de Janeiro encouraged the conflitcts of lands in cidades-entreposto, like São Paulo.

\section{Keywords}

municipal administration $\bullet$ urban land $\bullet$ colonial commerce.

\section{Contact}

Faculdade de Ciências Humanas e Sociais /UNESP

Avenida Eufrázia Monteiro Petráglia, n. 900

14409-160 - Jardim Petráglia - Franca - São Paulo

E-mail: dmsoa1@yahoo.com.br

This text is a version very much modified and that it was more developmented of one research communication presented in the XV Congress of AHILA, in the thematic symposiun "Independency, transforamtion of land and struggles in the Latin American (1808-1850) whose coordinators were the professors Vera Lúcia do Amaral Ferline and José Tengarrinha. This symposium happened in Leiden, Holland. The FAPESP and CNPq, in some moments, got me financial conditions to do research and studies that get support the ideas presented here. 
A partir da segunda metade do século XVIII, as políticas econômicas da Coroa portuguesa para os seus domínios na América, aplicadas por seus secretários de estado e governadores, tiveram como alvo o fomento e a diversificação da produção agrária. O horizonte do período apontava para o esgotamento das riquezas exploradas nos sertões minerais. ${ }^{1}$

A capitania de São Paulo, que até então tinha uma sólida tradição mercantil de abastecimento interno, ${ }^{2}$ passou a contar com uma política régia de incentivo à exteriorização de sua produção através do porto de Santos, o que levou à especulação e à individualização das terras que formavam o sítio da cidade de São Paulo.

Esta política de exteriorização da economia da capitania está relacionada ao contexto maior de reordenamento do poder do Império no centro-sudeste-sul do território da América portuguesa, cujos marcos podem ser considerados a implantação do Tribunal da Relação (1751), a transferência da sede administrativa da colônia para o Rio de Janeiro (1763) e a reabilitação da autonomia administrativa de São Paulo (1765), que coincidiu com a criação das tropas auxiliares. ${ }^{3}$ Tal política promoveu, ainda, uma competição entre a intenção atlantizadora dos governadores e as pretensões costeiras dos negociantes que atuavam tanto na cidade de São Paulo como na vila de Santos. ${ }^{4}$

1 Refiro-me, em especial a fase das medidas mercantilistas do Ministério do marquês de Pombal e sob o reinado de d. José I, entre 1750-1777, e ao período seguinte, dominado pelas secretarias de estado de d. Martinho de Melo e Castro (1770-1795) e de d. Rodrigo de Souza Coutinho (1796-1801). Para uma contextualização breve, mas profunda, destes dois momentos, cf. SCHWATZ, Stuart B. The economy of the Portuguese Empire. In: BETHENCOURT, Francisco \& CURTO, Diogo Ramada. Portuguese oceanic expansion, 1400-1800. EUA: Cambridge Press, 2007, p. 34-44.

2 Cf. ZEMELLA, Mafalda P. O abastecimento da capitania das Minas Gerais no século XVIII. $2^{\mathrm{a}}$ ed. São Paulo: Hucitec, 1990; BLAJ, Ilana. A trama das tensões: o processo de mercantilização de São Paulo colonial (1681-1721). São Paulo: Humanitas/FFLCH/USP-Fapesp, 2002; BORREGO, Maria Aparecida de Menezes. A teia mercantil: negócios e poderes em São Paulo (1711-1765). Tese de Doutorado, FFLCH/USP, São Paulo, 2006.

3 As milícias são um exemplo de tropas auxiliares, organizadas no fim do século XVIII, formadas por população da colônia recrutada, obrigada a prestar o serviço militar sem remuneração. Cf. PRADO Jr., Caio. Formação do Brasil contemporâneo. São Paulo: Ed. Martins, 1942, p. 309.

4 Para uma historiografia cuja base empírica efetivamente traça o perfil social e econômico dos negociantes que atuavam na cidade de São Paulo, entre o século XVIII e o início do XIX, ler PETRONE, Maria Thereza Schorer. O barão de Iguape: um empresário da época da independência. São Paulo: Ed. Nacional/Brasília/INL, 1976 (Col. Brasiliana, 361); LEONZO, Nanci. Um empresário nas milícias paulistas: o brigadeiro Luis Antonio de Souza. Anais do Museu Paulista. Tomo 30, 1980/81, p. 241-254; RABELLO, Elizabeth Darwiche. Os comerciantes na sociedade paulistana na primeira metade do século XIX. Tese de Livre-Docência, Assis/SP, 1988; ARAÚJO, Maria Lúcia Viveiros. Os caminhos das riquezas dos paulistanos na primeira metade do Oitocentos. São Paulo: Ed. Hucitec/Fapesp, 2006 e BORREGO, Maria Aparecida Menezes, op. cit. Muitos dos negociantes que atuavam na vila de Santos viviam na cidade de São Paulo, como mostrou esta historiografia. 
A política de viabilização da atividade portuária da capitania de São Paulo, em especial através do porto de Santos, iniciada em 1765, mas fortalecida somente a partir da década de 1780, faz pensar que a ação de reorientação política do Império em favor do Rio de Janeiro implicava também em reorganizar o poder na capitania de São Paulo que estivera subordinada ao Rio entre 1765-1748 e cuja principal vila litorânea, Santos, tinha históricas e cada vez mais sólidas ligações mercantis com a praça carioca. ${ }^{5}$

A capitania de São Paulo também encontrava-se em franca evolução demográfica, ${ }^{6}$ justificando a criação das tropas auxiliares no mesmo momento de sua autonomização administrativa, pois, com governo próprio, poderia dar andamento ao recrutamento dos homens em idade e condições físicas adequadas para a defesa da fronteira sul da América portuguesa.

A princípio pode parecer estranho que o incentivo à atividade mercantil na então vila e praça de Santos pudesse também interferir na estrutura fundiária da cidade de São Paulo. Caio Prado Jr., contudo, deixou uma perspicaz observação, que permite explicar e tomar como um bom ponto de partida para pesquisa, de que, ao longo de todo o litoral sul da América portuguesa, existiram cidades que funcionaram como sistemas, conjugadas às cidades portuárias.

Ao longo de toda a serra do Mar existiram estas "cidades conjugadas" como era o caso de Parati-Cunha, Ubatuba-São Luís do Paraitinga, São SebastiãoParaibuna, Paranaguá-Curitiba, no Paraná, e São Francisco-São Bento, em Santa Catarina. ${ }^{7}$ No sistema Santos-São Paulo, quanto mais intensa a atividade mercantil na vila marítima, maior era a movimentação de tropas condutoras de produtos coloniais ou europeus e asiáticos no perímetro da cidade que, assim como Macau, na China, funcionava também como um entreposto comercial. ${ }^{8}$

\footnotetext{
MOURA, Denise A Soares de. O porto de Santos como polo resdistribuidor de mercadorias coloniais no funcionamento do organismo colonial português (1765-1822). In: Anais do III Encontro de História Colonial MNEME. Revista de Humanidades. UFRN, Caicó, (RN), v. 9, n. 24, set/ out., 2008, 24 p. disponível em www.cerescaico.ufrn.br/mneme/anais. Acesso em: 12 de julho de 2010; MEINZ, Maximiliano Max. Centro e periferias coloniais: o comércio do Rio de Janeiro com Santos e Rio Grande (1802-1818). Revista de História. Dep. de História da USP, n. 154, 2006. O porto de Iguape também tinha sérios vínculos com o Rio de Janeiro mas não será objeto deste texto. Cf., contudo, VALENTIN, Agnaldo. Comércio marítimo de abastecimento: o porto de Iguape (São Paulo), 1798-1880. www.abphe.org.br/congresso2003/Textos/Abphe_2003_73.pd.

6 MARCÍlIO, Maria Luiza. Crescimento demográfico e evolução agrária paulistā, 1700-1836. São Paulo: Hucitec/Edusp, 2000.

7 PRADO Jr, Caio. Contribuição para a geografia urbana da cidade de São Paulo. Evolução política do Brasil e outros estudos. $8^{\mathrm{a}}$ ed. São Paulo: Brasiliense, 1972, p. 117.

8 BOXER, Charles. Portuguese society in the tropics: the municipal concils of Goa, Macau, Bahia and Luanda, 1580-1800. Madison and Milwaukee: The University of Wisconsin Press, 1965, p.
} 
Além de área produtiva e mercantil, como já demonstrado pela historiografia, a cidade de São Paulo era passagem obrigatória para a vila de Santos e oferecia, em seu termo e rossio, ${ }^{9}$ terrenos adequados para a instalação de hospedarias e pastos para o periódico descanso das tropas de animais que transportavam mercadorias. Estas condições físicas favoráveis estimularam a especulação das terras concedidas pela câmara em mercê ou por pagamento de foro, o fechamento dos tradicionais terrenos de servidão pública e o desincentivo aos antigos aldeamentos indígenas que foram transformados em freguesias. ${ }^{10}$

A política de terras nas vilas e cidades foi um dos instrumentos de legitimação da autoridade da câmara. Através desta política, assim como de outras, como a dos contratos públicos de abastecimento, ${ }^{11} \mathrm{a}$ instituição camarária enfrentava as pressões régias contra o seu poder, impostas por funções implantadas no Império como a dos juízes letrados, os juízes de fora, instituídos no final do século XVII, e pelo caráter mais formal do que funcional da divisão das funções da administração colonial que determinava certo nível de incerteza aos poderes. ${ }^{12}$

Mas além de instrumento de afirmação do poder da câmara, a estrutura fundiária da cidade de São Paulo foi desenhada de acordo com as disputas entre autoridades municipais, instituições religiosas e proprietários individuais. Estes útlimos envolviam uma complexa e diversificada camada social, munida ou não do registro da terra que ocupava. Somente uma investigação minuciosa e

46. Considerar, contudo, que existe historiografia que também comprova o caráter produtivo e mercantil da cidade. Cf. MOURA, Denise A. Soares. Um mercado em diversificação: produção e comércio da aguardente em São Paulo (1798-1822) texto inédito; MOURA, Denise A Soares de. Sociedade movediça: economia, cultura e relações sociais em São Paulo (1808-1850). São Paulo: Ed. Unesp, 2006; ARAÚJO, Maria Lucília Viveiros, op. cit.; BORREGO, Maria Aparecida Menezes, op. cit.

9 O termo era o território no qual era exercida a autoridade municipal. O rossio era parte do termo e patrimônio da Câmara, demarcado junto ao núcleo urbano, utilizado em servidão pública para pastagem de animais domésticos dos moradores, extração de lenha. Cf. MATTOSO, Kátia. Bahia: a cidade do Salvador e seu mercado no século XIX. São Paulo/Salvador: Ed. Hucitec/Secretaria Municipal de Educação e Cultura, 1978, p. 116.

${ }^{10}$ Para uma discussão sobre o caráter civilizador e laicizador destas ações, em especial sob a governadoria do morgado de Mateus, cf. TORRÃO FILHO, Amilcar. Paradigma do caos ou cidade da conversão: São Paulo na administração do morgado de Mateus (1765-1775). São Paulo: Ed. Annablume/Fapesp, 2007, cap. IV.

${ }^{11}$ MOURA, Denise A. Soares de. Região, relações de poder e circuitos mercantis em São Paulo. Revista Saeculum, n ${ }^{\circ}$. João Pessoa: Universitária UFPB, 2006.

${ }^{12}$ PRADO Jr., Caio. Formação..., op. cit., p. 297. Para um quadro bem detalhado e discutido dos constantes conflitos entre ouvidores, provedores, juízes de fora corregedores cf. JESUS, Nauk Maria. Na trama dos conflitos: administração na fronteira oeste da América portuguesa (17191778). Tese de Doutorado, Dep. de História da UFF, 2006 e COMISSOLI, Adriano. Os "homens bons" e a câmara de Porto Alegre (1767-1808). Dissertação de Mestrado, UFF, Niterói, 2006. 
quantificadora em documentação seriada, como os maços de população ou os inventários poderão conceituar com precisão este segmento.

Em relação a esta camada social, a intenção deste texto é apenas a de mostrar sua movimentação institucional ou informal, os conflitos em que se envolveu, os acordos que realizou visando assegurar sua propriedade individual ou os usos coletivos da terra conforme pregava a tradição e o costume. A documentação que utilizo é de caráter administrativo e judicial.

Ações especulativas individuais, principalmente de instituições religiosas e de ocupantes das terras urbanas, com registro formal ou não, passaram a disputar com um dos argumentos da dogmática administrativa colonial, de herança portuguesa e que prezava o bem coletivo e a boa administração da cidade. ${ }^{13}$

No Reino, neste mesmo período, juristas e memorialistas defendiam a formalização do registro e demarcação das terras, as sesmarias e o uso fundiário produtivo, o que explica o próprio decreto de 1795 de d. Maria I, que durou apenas um ano, mas demonstrava a força da concepção individual em torno do acesso à terra. Posteriormente, na conjuntura das cortes constituintes, as sesmarias foram condenadas, mas no item uso produtivo que impedia a consagração do pleno direito de propriedade. ${ }^{14}$

Mesmo após a independência, quando a Constituição de 1824 consagrou a propriedade da terra e a tendência foi de fortalecimento do poder provincial e do chefe do polícia, com a promulgação de leis - como a de 1828, que restringiu as atribuições das câmaras às meramente administrativas, o ato adicional de 1834 , que ampliou os poderes das assembleias legislativas provinciais, e a lei de 1841, que instituiu o chefe de polícia -, a câmara persistiu no exercício de suas costumeiras funções judiciais sobre as questões fundiárias da cidade, equilibrando sua autoridade entre um e outro grupo social, conforme a circunstância histórica.

Pesquisas já apontaram a existência de diferenças jurídicas entre os terrenos na cidade e no meio rural na tradição portuguesa moderna, com ressonâncias em seus domínios ultramarinos. ${ }^{15}$ Logo, uma reflexão sobre a terra na cidade da América portuguesa implica também pensar num problema corrente da historiografia mais recente como o da luta dos conselhos municipais para preservar sua identidade e autoridade local, no cerne de uma estrutura monárquica e em meio à concorrência de poderes. ${ }^{16}$

\footnotetext{
${ }^{13}$ HESPANHA, Antonio Manuel. Às vésperas do Leviathan: instituições e poder político. Portugal, século XVII. Coimbra: Liv. Almedina, 1994.

${ }^{14}$ Esta discussão cf. em MOTTA, Márcia M. M. Direito à terra no Brasil: a gestação do conflito, 1795-1824. São Paulo: Ed. Alameda, 2009.

${ }^{15}$ GLEZER, Raquel. Chãodeterraeoutros ensaios sobreSãoPaulo. SãoPaulo:Ed.Alameda,2007,p. 114.

${ }^{16}$ GREENE, Jack P. Negotiated authorities: essays in colonial political and constitutional history.
} 


\section{Brigas por terra nas cidades coloniais}

As cidades coloniais da América portuguesa, posteriormente, com a independência, também viveram a experiência dos conflitos de terra. Bicalho identificou este problema no final do século XVII, quando a Câmara do Rio de Janeiro desentendeu-se com o governador pela decisão, em acórdão, de que vendesse suas posses em chãos da marinha para a geração de recursos que seriam investidos em obras públicas reais. ${ }^{17}$

Entre o final do século XVIII e o início do XIX, contudo, esses conflitos também estiveram relacionados ao incremento da atividade mercantil, tanto motivado pela política do Império, como pela posterior diversificação dos parceiros comerciais estrangeiros do Brasil, promovida pela abertura dos portos em 1808 .

Os tratados de 1810 assinados entre Portugal e Inglaterra ${ }^{18}$ intensificaram a presença britânica nas principais praças mercantis do território do Brasil, elevando o volume das importações de produtos manufaturados que, redistribuídos no interior através das vilas marítimas menores, incentivavam novas formas de uso e ocupação dos terrenos das cidades, principalmente naquelas que também funcionavam como entreposto e recebiam diariamente cargueiros de animais conduzindo mercadorias. ${ }^{19}$

Alguns autores chegam a afirmar que as tensões do período foram próprias da crise de valores de uma sociedade de Antigo Regime e emergência de uma consciência individual própria do liberalismo. ${ }^{20}$ Mas como as disputas em torno dos chãos de terra das cidades coloniais existiam desde longa data, também convém pensar que, para além das novas ideologias, muitas das tensões sociais de uma época eram movidas por razões práticas que, para o período e espaço tratado neste texto, dizem

The University Press of Virginia, 1994; BICALHO, Maria Fernanda Baptista. A cidade e o império: o Rio de Janeiro no século XVIII. Rio de Janeiro: Ed. Civilização Brasileira, 2003, p. 201-3 e SOBRAS NETO, Margarida. Senhorios e concelhos na época moderna: relações entre dois poderes concorrentes. In: CUNHA, Mafalda Soares e FONSECA, Teresa (org.). Os municipios no Portugal moderno: dos forais manuelinos às reformas liberais. Évora: Edições Colibri/ Cidehus/EU, 2005, p. 149-165.

${ }^{17}$ BICALHO, Maria Fernanda, op. cit., p. 204-205.

${ }^{18}$ Em termos comerciais, o tratado de 1810 previa cobrança do valor de $15 \%$ sobre as mercadorias inglesas, $16 \%$ sobre as portuguesas e $24 \%$ sobre as das outras nações.

${ }^{19}$ Sobre a movimentação de tropas de animais na cidade de São Paulo conduzindo mercadorias cf. De memorialistas à historiografia mais recente. Viajantes europeus registram esta movimentação na cidade. BRUNO, Ernani Silva. História e tradições da cidade de São Paulo. 4 ed. São Paulo: Ed. Hucitec, 1991, vols. 1 e 2; MOURA, Denise A. Soares de. Sociedade movediça, op. cit.; LAGO, Pedro Correa. Iconografia paulistana do século XIX. São Paulo: Bolsa de Mercadorias \& Futuros, 1998.

${ }^{20}$ Cf. MOTTA, Márcia M. M., op. cit. 
respeito às novas oportunidades econômicas surgidas com o declínio dos monopólios e a consolidação britânica no comércio de manufaturados com o Brasil.

De um modo geral, estruturas e conflitos fundiários na história da América portuguesa e do período pós-independência são associados ao universo rural, não sendo levados em consideração os espaços das cidades. ${ }^{21}$ Bicalho, contudo, valorizou a questão, ressaltando as divergências entre a câmara e autoridades régias, como a do provedor, em relação aos chãos de terra da marinha do Rio de Janeiro e entre a câmara e os "moradores da cidade". 22

Raquel Glezer escreveu que questões de apropriação, propriedade e posse dos terrenos da cidade foram motivadas por relações socioeconômicas tão complexas quanto as do meio rural, ${ }^{23}$ podendo ser acrescentadas ainda as razões de ordem política e de governabilidade, como a legitimação de autoridades, a necessidade de assegurar o funcionamento do espaço administrado e a existência de grupos e interesses específicos que gravitam em torno ou estão diretamente ligados às instituições de governo.

Nos estudos, investigações e reflexões sobre a terra rural e das cidades existem pelo menos dois marcos: ao longo de todo o período colonial e até 1822 , a lei de sesmarias; no século XIX, a lei de 1850. Esta última determinava que a aquisição das terras devolutas restringir-se-ia à compra, seriam mantidos os campos de uso comum dos moradores das freguesias, municípios ou comarcas, o domínio público seria diferenciado do particular, as terras do poder público seriam discriminadas das devolutas e caberia ao governo definir quais terras devolutas

${ }^{21}$ Cf. MARTINS, José de Souza. O cativeiro da terra. São Paulo: Ed. Hucitec, 1979; COSTA, Emília Viotti da. Política de terras no Brasil e nos EUA. In: Da Monarquia à República: momentos decisivos. São Paulo: Ed. Grijalbo, 1977, p. 127-147; GADELHA, Regina. A lei de terras (1850) e a abolição da escravidão: capitalismo e força de trabalho no Brasil do século XIX. Revista de História. São Paulo, jan/jul 1989, p. 153-162; MOTTA, Márcia M. M. Nas fronteiras do poder: conflito e direito à terra no Brasil do século XIX. Rio de Janeiro: Arquivo Público do Estado do Rio de Janeiro/Vício de Leitura, 1998 e Direito à terra..., op. cit.; LIMA, R. C. Pequena história territorial do Brasil. Sesmarias e terras devolutas. 2a ed. Porto Alegre: Editora Sulina, 1954; PORTO, C. Estudo sobre o sistema sesmarial no Brasil. Brasília: EdUnB, 1979/1980; NOZOE, Nelson. Sesmarias e apossamentos de terras no Brasil colônia. Revista Economia. Brasília (DF), v. 7, n. 3, set/dez. 2006, p. 561-586. Cf. também os números da Revista Brasileira de História: 22 (1991), 46 (2003) e 53 (2007). As duas últimas intituladas respectivamente "Experiências urbanas" e "Cidades", sendo que em nenhum delas existem artigos que enfocam a terra na cidade colonial e seus problemas. As indicações e advertências de Raquel Glezer ainda são válidas. Alguns estudos concluíram por um processo linear de laicização dos usos e ocupação dos terrenos urbanos, com a passagem de uma tônica essencialmente religiosa para uma outra, de natureza secular. Cf. MARX, Murilo. Nosso chão: do sagrado ao profano. São Paulo: Edusp, 1989.

${ }^{22}$ BICALHO, Maria Fernanda, op. cit., p. 206 e 210-220.

23 'GLEZER, Raquel, op. cit., p. 54. 
seriam para colonização dos indígenas, fundação de povoações, aberturas de estradas, servidões, estabelecimentos públicos e construção naval. ${ }^{24}$

Durante certo tempo, a lei de 1850 foi considerada referência explicativa para a instauração de um mercado de terras no Brasil no sentido capitalista ou esteve vinculada ao problema da transição do trabalho escravo ao livre, tendo em vista que sua promulgação coincidiu com a abolição do tráfico negreiro. ${ }^{25}$ Contudo, desde a segunda metade do século XVIII, já existia um incipiente mercado imobiliário nas cidades coloniais. Em São Paulo, ele era movimentado pela venda de datas de terras e, no Rio de Janeiro, pelos enfiteutas que as arrendavam a particulares por preços exorbitantes. ${ }^{26}$

Em São Paulo, mesmo após 1850, com o registro das terras possuídas e a definição do perímetro urbano pela área através da Décima Urbana, ${ }^{27}$ permaneceram as delimitações tradicionais do termo e do rossio, conforme ocorria na colônia. ${ }^{28}$

Tanto na cidade imperial persistiram "direitos imemoriais", como na cidade colonial se esbateram ações costumeiras e ações individuais, especulativas, aproveitadoras das oportunidades abertas pela intensificação da atividade mercantil que descia e subia a serra do Mar, o que obriga a ponderação de qualquer interpretação mais linear da transição entre os séculos XVIII e XIX para um clima de opinião liberal.

Um campo de forças entre costume e iniciativas novas, com aparência de liberais, existiu em torno dos terrenos na cidade de São Paulo e este é o tema deste artigo. Em grande medida, o ensaio de Giovanni Levi, intitulado "Reciprocidade e comércio da terra" ${ }^{29}$ inspira as questões levantadas na documentação camarária do Arquivo Municipal de São Paulo e algumas ações de Força-Nova, ${ }^{30}$ parte do conjunto documental autos-cíveis, sob a guarda do Arquivo do Estado.

${ }^{24}$ Idem, p. 62. Para acompanhar os debates sobre o projeto da lei de terras na câmara e no senado imperial, cf. MOTTA, Márcia M. Nas fronteiras..., op. cit.

${ }^{25}$ Marcia Motta mostrou que a lei de 1850 expressou uma arena de lutas entre diferentes concepções de direito de terra, de acordo com as várias experiências - de sesmaria e posse-do passado colonial. Cf. MOTTA, Márcia M. M. Sesmeiros e posseiros nas malhas da lei (um estudo sobre os debates parlamentares acerca do Projeto de Lei de Terras - 1843/1850). In: Raízes, n. 18, setembro/98, 102-110.

${ }^{26}$ GLEZER, Raquel, op. cit., p. 98. BICALHO, Maria Fernanda, op. cit., p. 210-220.

${ }^{27}$ Imposto sobre os prédios urbanos criado pelo alvará de 27 de junho de 1808, que determinava que todos os proprietários de prédios urbanos deviam pagar anualmente para a Fazenda Real $10 \%$ do rendimento líquido. Prédios urbanos compreendiam os que estivessem nas demarcações das câmaras respectivas. Cf. GLEZER, Raquel, op. cit., p. 72.

${ }^{28}$ Idem, p. 68.

${ }^{29}$ LEVI, Giovanni. A herança imaterial: trajetória de um exorcista no Piemonte do século XVIII. Rio de Janeiro: Civilização Brasileira, 2000.

${ }^{30}$ As ações de Força Nova envolviam reclamação judicial de posse territorial antes de completar um ano da força cometida. 
Neste texto, a problematização do tema proposto através de comportamentos individuais - o que não quer dizer análise prosopográfica - é uma forma de compreender o social como complexa rede de relações, multiplicidade de espaços e tempos, "conjunto de inter-relações móveis dentro de configurações em constante adaptação". Acredito que a abordagem micro-histórica enriquece a análise social, pois valoriza "aspectos diferentes, inesperados, multiplicados da experiência coletiva". ${ }^{31}$

A investigação sobre a terra nas cidades da América portuguesa exige a pesquisa e reflexão sobre a autoridade municipal ${ }^{32}$ que deve ser entendida não como unidade autárquica, mas obrigatoriamente funcionando através da "complexa e variável imbricação das diversas fontes de poder e de autoridade local e das personagens que lhe davam corpo (o juiz, o pároco, o capitão de ordenanças etc.). ${ }^{33}$

\section{O senado da câmara e a administração das terras da cidade}

Embora as câmaras tenham sido a base da ocupação e colonização especialmente das principais partes do território da América portuguesa ${ }^{34}$ desde o início do século XVIII, com a exploração mineral nos sertões de Minas Gerais e do oeste do continente, estas instituições passaram a enfrentar mais diretamente a concorrência e interferência de autoridades letradas diretamente indicadas pelo rei, como o governador, o juiz de fora, o corregedor e o provedor. ${ }^{35} \mathrm{O}$ juiz de fora, contudo, não apareceu no senado da câmara da cidade de São Paulo antes de $1810,{ }^{36}$ diferente do que aconteceu com a Vila Real do Cuiabá que, desde 1777, já tem notícia de sua presença nos registros municipais, assim como na cidade do Salvador que aparece na documentação desde $1700 .^{37}$

${ }^{31}$ REVEL, Jacques. A história ao rés do chão, In: LEVI, Giovanni, op. cit., p. 7-37.

32 BICALHO, Maria Fernanda, op. cit.

${ }^{33}$ MONTEIRO, Nuno Gonçalo. Os poderes locais no Antigo Regime. In: OLIVEIRA, César (dir.). História dos municípios e do poder local: dos finais da Idade Média à União Europeia. Lisboa: Círculo de Leitores, 1996, p. 19.

${ }^{34}$ Considero deste modo porque Caio Prado Jr. lembra que, em algumas partes da colônia, nas vilas menos importantes e periféricas, às vezes não havia gente suficiente ou interessada em ocupar cargos camarários, de modo que o capitão-mor terminava por ser o agente mais atuante e de maior prestígio que a própria instituição municipal.

${ }^{35}$ Para um tratamento minucioso destas questões cf. JESUS, Nauk Maria, op. cit., e CAMPOS, Maria Verônica. Goiás na década de 1730: pioneiros, elites locais, motins e fronteira. In: BICALHO, M. F. B. e FERLINI, Vera Lúcia A. (org.). Modos de governar: ideias e práticas políticas no Império Português. São Paulo: Ed. Alameda, 2005. Para as implicações deste processo em termos de memória e imaginário veja ROMEIRO, Adriana. Paulistas e emboabas no coração das minas: ideias, práticas e imaginário político no século XVIII. Belo Horizonte: Ed. UFMG, 2008.

${ }^{36}$ KUZNESOF, Elizabeth Anne. Household economy and urban development. EUA: Westview, 1986, p. 24.

${ }^{37}$ Cf. JESUS, Nauk Maria de, op. cit., p. 258 e 306; SOUSA, Avanete Pereira. Poder local, cidade e atividades economicas (Bahia, século XVIII). Tese de Doutorado, FFLCH/USP, 2003, p. 68-9. 
Esta situação sugere o quanto o poder régio mantinha relações distintas com suas áreas, inclusive num mesmo território, agindo conforme o papel que cada área desempenhava na estrutura do Império nas circunstâncias históricas específicas. Na parte mais ao sul do continente, incluindo São Paulo, a disposição da Coroa portuguesa em interferir mais diretamente no poder municipal surgiu na primeira metade do século XIX. ${ }^{38}$

Subordinadas ou não a um juiz de fora, a tendência das várias instituições municipais na América portuguesa, contudo, foi a de reforçar sua autoridade na administração urbana, seja na manutenção da ordem pública, no abastecimento ${ }^{39}$ ou na questão da concessão e uso dos terrenos da cidade.

As câmaras tinham patrimônio e finanças próprias, independentes do Real Erário. O patrimônio era formado pelas terras concedidas na ocasião da criação da vila, que formavam o rossio, destinado para logradouros e edificações e para formação dos pastos públicos. A câmara podia conceder ou aforar a particulares parte de seu patrimônio fundiário, os ditos bens do conselho. ${ }^{40}$

Este é um importante diferencial em relação à terra rural, que fazia parte da alçada régia, ou seja, os chãos da cidade eram de domínio do município e não havia uma legislação específica para este assunto. Segundo Raquel Glezer, todas as Ordenações do Reino - manuelinas, afonsinas e filipinas - trataram dispersamente deste problema, sem formar um conjunto coerente de regras, algo que pode ser explicável, contudo, pela própria inexistência de uma noção de urbano no período. ${ }^{41}$

Contudo, em termos práticos, esta dispersão da legislação sobre a terra da cidade pode ter favorecido certas confusões em relação aos bens comuns do conselho, cujas áreas eram destinadas ao uso comum dos habitantes da vila ou cidade e os bens do conselho propriamente ditos, ou seja, as áreas para concessão e aforamento.

O rossio, que nas cidades da América portuguesa tomou o lugar do termo e persistiu até o século XIX, embora fosse um bem comum do conselho, muitas vezes, algumas de suas partes foram concedidas em "datas de terra". Esta concessão de terras do rossio, que deveriam ser de uso comum da população, pode ter sido motivada tanto por um desconhecimento das determinações da lei, considerando-se as limitações de acesso ao texto das ordenações sofridas pelos

${ }^{38}$ Em Porto Alegre a vara de juiz de fora foi instituída somente em 1803. Cf. COMISSOLI, Adriano, op. cit, p. 123.

${ }^{39}$ GOUVEIA,MariadeFátimadaSilva.Poder, autoridadeeoSenadodaCâmaradoRiode Janeiro, ca. 17801820. Teтро. Universidade Federal Fluminense, Departamento de História, v. 7, n. 13, 2002, p. 111-155.

${ }^{40}$ PRADO Jr., Caio. Formação..., p. 314.

${ }^{41}$ GLEZER, Raquel, op. cit., p. 116. Para uma crítica à aplicação da noção de urbano do século XIX na interpretação da cidade colonial, cf. TORRÃO FILHO, Amilcar, op. cit. 
conselhos na colônia, como por uma concepção extrema de "bem do conselho" que sobrepôs à própria noção de "bem comum". ${ }^{42}$ Pode-se considerar, ainda, as conjunturas em que interesses particulares no ou em torno do conselho tenderam a prevalecer em relação aos da própria administração do município. ${ }^{43}$

Se as câmaras de algumas cidades coloniais enfrentavam, desde o final do século XVII, desafios periódicos de assegurar sua identidade e legitimidade na localidade e ao mesmo tempo ser formada ou ter gravitando em torno de si interesses particulares de grupos específicos, na administração da terra da cidade, estas instituições estiveram divididas entre atender solicitações de concessão e favor individual, o que as levavam a conceder partes das áreas de uso comum ao bem particular e ao mesmo tempo garantir o "bem comum" dos habitantes. Estudos concluíram que as terras de uma povoação, vila ou cidade tinham regulamentação específica e diferente das terras rurais, existindo o "termo, área jurisdicional da câmara, as 'terras de uso comum', os foros e laudêmios, terras de uso e finalidades públicas, com um tributo, a Décima urbana, sobre prédios". ${ }^{4}$

Esta constatação incentiva a hipótese de que a administração da terra urbana nas cidades da América portuguesa e mesmo do Brasil independente foi esfera de afirmação da autoridade da câmara diante de uma política de restrição de seus poderes legais que tanto se deu no período de subordinação à Coroa portuguesa como no da Regência. As câmaras enfrentaram muitos desafios na preservação de sua identidade e autoridade e as conjunturas de expansão econômica e modificações políticas trazem problemas para se pensar sobre isto.

\section{O sistema São Paulo-caminho do Mar-Santos em conjunturas expansivas in- terferindo na estrutura fundiária da capital da capitania}

O funcionamento conjugado do sistema São Paulo-Santos, ${ }^{45}$ através do caminho do Mar, adquiriu caráter político e mercantil especialmente a partir da

\footnotetext{
${ }^{42}$ Idem, 118.

${ }^{43}$ BICALHO, Maria Fernanda, op. cit., p. 211.

${ }^{44}$ GLEZER, Raquel, op. cit. p. 65.

${ }^{45}$ Como obra pioneira em apontar este problema, PRADO Jr., Caio. Contribuição... op. cit., p. 117. Como pesquisa que desenvolve esta questão, própria da segunda metade do século XVIII, cf. TORRÃO FILHO, Almílcar, op. cit. Antes de ser um problema do Império, o caminho do Mar, mesmo com suas difíceis condições de acessibilidade, já funcionava como um importante organismo mercantil da capitania. Cf. HOLANDA, S. B. Movimentos de população..., op. cit.; BLAJ, Ilana. A trama das tensões: o processo de mercantilização de São Paulo colonial (1681-1721). São Paulo: Humanitas/ FFLCH/USP-Fapesp, 2002 e BORREGO, Maria Aparecida de Menezes. A teia mercantil: negócios e poderes em São Paulo (1711-1765). Tese de Doutoramento, FFLCH/USP, São Paulo, 2006.
} 
segunda metade do século XVIII, com a retomada da autonomia administrativa da capitania de São Paulo. ${ }^{46}$ Aos governadores gerais coube a missão de fomentar a produção e comércio dos domínios coloniais portugueses na América, como parte do esforço oficial de revitalização do sistema colonial e da economia portuguesa, especialmente da sua indústria e da sua inserção no comércio internacional.

Na capitania de São Paulo, as reformas político-administrativas-econômicas de d. José, sob o ministério pombalino, ${ }^{47}$ significaram o incentivo a produção agroexportadora do açúcar. ${ }^{48}$ Posteriormente, no governo de Bernardo José de Lorena (1788-1797), já entre as secretarias de estado de d. Martinho de Melo e Castro (1770-1795) e de d. Rodrigo de Souza Coutinho (1796-1801), ocorreu a intensificação e diversificação da atividade mercantil na principal vila marítima da capitania, Santos, estimulada por uma política de pavimentação do caminho do Mar.

No reinado de d. Maria I, que impôs severas restrições à atividade industrial no Brasil com o alvará de 1785, e na regência de d. João VI, parecem ter residido as motivações para o aperfeiçoamento do comércio colonial do Império, com o fortalecimento de polos periféricos de exportação de produtos coloniais para as principais praças mercantis e redistribuição de mercadorias europeias que levaram aos esforços do governador Lorena em fazer do porto de Santos único exportador na costa da capitania.

A intensificação de movimentação mercantil na vila de Santos, especializada no comércio costeiro de produtos coloniais e na redistribuição de produtos europeus serra acima em direção ao interior, é algo que vem sendo constatada por algumas investigações. ${ }^{49}$ Embora a Coroa portuguesa, desde o governo do morgado de Mateus na capitania, tenha procurado reforçar os tratos mercantis entre o porto de Santos e o Reino, ${ }^{50}$ a tendência foi de prevalecimento do comércio costeiro, de norte a sul.

O comércio colonial português parece ter reforçado a hierarquia entre as praças mercantis, tornando algumas especializadas no fornecimento de mercadorias

${ }^{46}$ BELLOTTO, Heloísa Liberalli. Autoridade e conflito no Brasil colonial: o governo do morgado de Mateus em São Paulo. São Paulo: Conselho Estadual de Artes e Ciências Humanas, 1979.

${ }^{47}$ NOVAIS, Fernando A. Portugal e a crise do antigo sistema colonial (1777-1808). São Paulo: Hucitec, 1979; ARRUDA, José Jobson. Decadence or crisis in the Luso-Brazilian Empire: a new model of colonization in the Eigtheenth Century. In: Hispanic American Historical Review, 80: 4, 2000, p. 865-878; ALDEN, Dauril. O período final do Brasil colônia, 1750-1808. In: BETHELL, Leslie. História da América Latina colonial. Trad. de Mary Amazonas Leite de Barros e Magda Lopes. São Paulo: Edusp; Brasília: Fundação Alexandre de Gusmão, 1999, p. 527-592.

${ }^{48}$ PETRONE, Maria Thereza Schorer. A lavoura canavieira em São Paulo. Expansão e declínio (1765-1888). São Paulo: Difusão Europeia do Livro, 1968.

49 MOURA, Denise A Soares de. O porto de Santos como polo redistribuidor..., op. cit.

${ }^{50}$ Destaco especialmente a atuação de d. Luis de Souza Botelho Mourão, o morgado de Mateus (17651775), e sua tentativa, juntamente com alguns negociantes da vila de Santos, de montar uma companhia de comércio direto com Lisboa. Cf. Atas da Câmara, v. 15, 1768, p. 326-335; p. 339-340; p. 344-46. 
coloniais e redistribuição de mercadorias europeias. A demanda por mercadorias coloniais nesse período era alta, destacando-se, no centro-sul, a praça mercantil do Rio de Janeiro, com uma elite de negociantes de grosso trato envolvida diretamente nos grandes circuitos atlânticos. ${ }^{51}$

As ligações do porto de Santos com portos da costa do Brasil foram diversificadas, o que indica seu nível de autonomia perante a praça do Rio de Janeiro, mas era com este porto que se davam seus maiores contatos.

Em termos numéricos, após a abertura dos portos e intensificação das importações de manufaturas da Inglaterra, portanto entre 1810-1818, estima-se que o volume dos negócios da vila de Santos com o Rio de Janeiro girou em torno de $57,7 \%$ das exportações e $76,9 \%$ das importações. ${ }^{52}$ Diferente das conclusões de Maximiliano M. Menz, verifica-se que as exportações de Santos podem não ter sido menos variadas e pode não ter ocorrido domínio total do açúcar. ${ }^{53}$

Sérgio Buarque de Holanda fala na exportação de couros, café, tabaco e algodão e que a diminuição do volume de exportações do açúcar foi relativamente compensada pelo crescimento vertical nas exportações de couros e arroz, que passaram respectivamente, entre 1801 e 1807 , de $298 \$ 400$ a $52 \$ 389 \$ 480$ e de $79 \$ 500$ a $45: 618 \$ 240 . .^{54}$

Considero a hipótese desse comércio de exportação de mercadorias coloniais no porto de Santos não ter sido resultado apenas dos circuitos mercantis costeiros com Iguape, Paranaguá, São Francisco do Sul, Rio Grande, Buenos Aires e Montevidéu, mas também dos negócios serra acima, realizados na cidade, conforme já demonstrou a historiografia citada e através do caminho do Mar. Nesta questão pode estar um dos motivos dos conflitos em torno da terra na cidade de São Paulo.

A princípio, pode-se considerar que esse circuito de mercadorias coloniais via caminho do Mar é impossível de quantificar, porque ele foi marcado pelo comércio ilegal, ou seja, pela presença regular dos atravessadores ou traficantes de mercadorias, que tanto aparecem na documentação da Câmara e foram muito

\footnotetext{
${ }^{51}$ FRAGOSO, João Luís R. Homens de grossa aventura: acumulação e hierarquia na praça mercantil do Rio de Janeiro (1790-1830). Rio de Janeiro: Civilização Brasileira, 1998; FLORENTINO, Manolo. Em costas negras: uma história do tráfico de escravos entre a África e o Rio de Janeiro (séculos XVIII e XIX). São Paulo: Companhia das Letras, 1997; ANTUNES, Luís Frederico Dias. Têxteis e metais preciosos: novos vínculos do comércio indo-brasileiro (1808-820). In: FRAGOSO, João Luís Ribeiro et alli. $O$ antigo regime nos trópicos: a dinâmica imperial portuguesa (séculos XVI-XVIII). Rio de Janeiro: Ed. Civilização Brasileira, 2001, p. 381-420.

${ }^{52}$ MENZ, Maximiliano M., op. cit., p. 256.

${ }^{53}$ Idem, p. 258.

${ }^{54}$ Cálculo realizado sobre os dados da tabela fornecida por S. B. Holanda. São Paulo. História geral da civilização brasileira. $6^{\text {a }}$ ed. Rio de Janeiro: Bertrand Brasil, tomo 2, vol. II, 1995, p. 419.
} 
tratados pela historiografia. ${ }^{55}$ Mas essa mesma documentação municipal traz avultada notícia de que os cargueiros de alimentos oriundos de outros municípios, principalmente de Bragança, Atibaia e Nazaré, eram constantes na cidade e a própria política do governador Lorena foi a de estimular a integração da produção do interior com o litoral, via caminho do Mar.

O comércio externo da capitania já havia sido incentivado anteriormente pelo morgado de Mateus, que, em 1768, sugeriu ao conde de Oieras que tomasse as mesmas providências dadas no Maranhão e Pará, estimulando a ligação direta do porto de Santos com o reino "porque os homens de negócio deste paíz costumados à sua antiga rotina de correspondência que tem para o Rio de Janeiro, donde the vem fazendas, a maior parte de Inglaterra não tratam de comprar gêneros da terra para os carregarem para o Reino, tendo já entrado quatro navios no porto de Santos, que vierão em direitura do dessa cidade, sairão outra vez para carregarem em o Rio de Janeiro, Bahia sem levarem deste paiz couza de entidade e isto faz com que se atrase a lavoura". ${ }^{56}$

As contínuas crises de abastecimento da cidade, informadas pela documentação municipal, também são indício de que gêneros coloniais, que serviam para alimentar a população, estavam sendo deslocados para mercados economicamente mais vantajosos, como os do porto de Santos e do Rio de Janeiro. A partir dessas duas praças, as mercadorias alimentavam o giro do comércio costeiro e atlântico. ${ }^{57}$

Um termo de vereança de 1793 debatia o impacto da notícia da falta de mantimentos na Bahia, Pernambuco, Angola e Benguela que tinha chegado "aos ouvidos de vários comerciantes" e "que movidos de ambição de aumentarem os seus interesses entraram a formar negociações" de vários gêneros, atravessando pelos portos da marinha desta capitania "toda a farinha, feijão e arroz que lhes foi possível: e não satisfeitos com este monopólio passaram a mandar várias pessoas disfarçadas" para a cidade e seu termo, onde tinham até então atravessado "para cima de 850 porcos e considerável número de alqueires de farinha, e feijão, tudo para transportarem para os diversos portos". Tais atravessadores andavam por

${ }_{55}$ MOURA, Denise A. S. Sociedade movediça..., op. cit.; BLAJ, Ilana, op. cit.; TORRÃO FILHO, Amílcar, op. cit. e BORREGO, Maria Aparecida Menezes, op. cit.

${ }^{56}$ Relação das cartas de serviço do governador e capitão general da capitania... morgado de Mateus... AHU, São Paulo, cx. 5, doc. 25, 1768. Documentos manuscritos avulsos da capitania de São Paulo, doc. n. 338.

${ }^{57}$ Sobre o papel das mercadorias coloniais no comércio atlântico cf. ALENCASTRO, Luiz Filipe. $O$ trato dos viventes: formação do Brasil no Atlântico sul, séculos XVI e XVII. São Paulo: Companhia das Letras, 2000; FLORENTINO, Manolo, op. cit.; MENZ, Maximiliano M. Entre dois impérios: formação do Rio Grande na crise do antigo sistema colonial (1777-1822). Tese de Doutorado, São Paulo, 2006. 
Nazareth, Atibaia e Jaguary, onde compravam todos os porcos, cevada, feijão e mandioca que encontravam. ${ }^{58}$

Sob a autoridade da patente, mais do que da farda, pois muitas eram as queixas da precariedade dos uniformes, milicianos eram frequentemente denunciados nas fontes municipais pelo desvio dos cargueiros de alimentos que entravam na cidade, como o reverendo padre capelão da Legião de Tropas Seguras, Antonio José Lesa, acusado de fazer "repetidas travessias" de farinhas, "com um escandaloso monopólio para as enviar para a vila de Santos e Rio de Janeiro". 59

Os próprios contratos públicos de abastecimento, tais como os do corte do açougue, aguardente, estancos nas freguesias e casinhas - mercado público da cidade - sofriam com a diminuição das arrematações, prejudicando também as rendas do conselho. $\mathrm{O}$ controle municipal sobre os preços de venda dos produtos era desestimulador para negociantes que poderiam ampliar sua margem de ganho vendendo para os atravessadores. Por isso, aparece com insistência na documentação camarária solicitações da câmara para a Real Fazenda para que tomasse providências contra essa venda traficante, mas era na tributação proporcionada pelo comércio de longa distância, terrestre, costeiro ou atlântico, que o Real Erário ampliava seus recursos. ${ }^{60}$

As vilas de Atibaia e Bragança, caminhos subsidiários para o sul de Minas Gerais, foram as que mais sofreram sanções do senado da Câmara de São Paulo, por apenas cruzarem a cidade com seus cargueiros, principalmente de farinhas, em direção a Santos.

Em certa ocasião se manifestaram contra as "violências com que os almotacéis (...) vexavão os lavradores, negociantes e comboeiros" de seus conselhos, obrigando-os a venderem nas casinhas pelo miúdo. Advertiam ainda que o capítulo da correição de 1812 havia estabelecido a "franqueza do comércio". ${ }^{61}$ De fato, nesse ano, o Desembargo do Paço determinou a liberdade de "exportação" dos víveres da capitania, sob pena de prisão aos almotacéis que agissem contra os que quisessem vender livremente suas mercadorias. Tratou-se de uma vitória das forças de liberalização dos mercados contra a política de controle das câmaras.

O Rio de Janeiro vinha se tornando um importante mercado consumidor e praça de exportação de gêneros coloniais desde 1763, quando alcançou o status de capital da América portuguesa. A internalização da corte em 1808 e o fim do mono-

\footnotetext{
${ }^{58}$ Atas da Câmara, v. 19, 1793, p. 368-72.

${ }^{59}$ Papéis avulsos, v. 9, 1811, p. 302.

${ }^{60}$ Atas da Câmara, v. 21, 1811, p. 206.

${ }^{61}$ Papéis avulsos, v. XIV, 1819, p. 258.
} 
pólio mercantil português fortaleceu ainda mais este mercado, ${ }^{62}$ o que estimulou a movimentação mercantil das vilas marítimas periféricas e do interior, serra acima, especialmente as cidades conjugadas do centro-sul da capitania de São Paulo.

Essa expansão das atividades mercantis no sistema São Paulo-Santos, através do caminho do Mar, teve impacto sobre a estrutura fundiária da cidade de São Paulo, abrindo um campo de fricção entre o direito colonia ${ }^{63}$ de concessão e uso da terra, representado pela câmara, e as ações individuais e especulativas de instituições e "senhores possuidores" de terrenos na cidade.

\section{Instituições religiosas e usos das graciosas mercês de terras}

Numa conjuntura na qual, no Reino, juristas e memorialistas defendiam a lei de sesmarias como um dos mecanismos de afirmação do direito português, em detrimento do até então prevalecente direito romano, ${ }^{64}$ e, na capitania de São Paulo, o morgado de Mateus iniciava sua política de fomento da produção e exteriorização do comércio da região, o senado da Câmara de São Paulo, em 1767, em defesa da tradicional política de concessão de datas de terra entrava em atritos com o Mosteiro de São Bento ${ }^{65}$ devido à especulação que faziam com os terrenos que possuíam por concessão na cidade, do mesmo modo como fazia a Ordem Terceira do Carmo no Rio de Janeiro. ${ }^{66}$

Graciosamente, os senadores de certo tempo, conforme informava o procurador do mosteiro, haviam concedido, em mercê aos religiosos, terras na ladeira e ponte do Anhangabaú, pela entrada da Luz até o Acú. Porém, "levados os religiosos de própria ambição e abusando da mercê que [o senado] lhes tinha feito livre de toda a pensão e sem prejuízo de terceiro entraram a aforar as mesmas terras (...) com prejuízo grande dos que as habitam, e ainda mais que percebendo

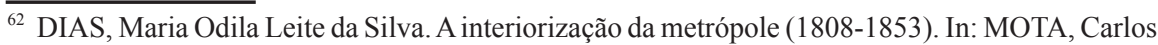
Guilherme. 1822: dimensões. $2^{a}$ ed. São Paulo: Ed. Perspectiva, 1986, p. 160-186; LENHARO, Alcir. As tropas da moderação. O abastecimento da corte na formação política do Brasil: 1808-1842. $2^{\mathrm{a}}$ ed. Rio de Janeiro: Secretaria Municipal de Cultura, Turismo e Esporte, 1993; GORENSTEIN, Riva. O enraizamento de interesses mercantis portugueses na região do centro-sul do Brasil: 1808-1822. Uma contribuição ao estudo do processo de estruturação da sociedade da independência. São Paulo: ME/FFLCH/USP, 1978 e OLIVEIRA, Cecília Helena. A astúcia liberal: relações de mercado e projetos políticos no Rio de Janeiro (1820-1824). São Paulo: Udusf/Ícone, 1999.

${ }^{63}$ A expressão é de Raquel Glezer, referindo-se ao direito de concessão de terras da câmara baseado no documento de doação de Martim Afonso de Sousa do território para a fundação da vila e São Paulo. Cf. Chão de terra e outros ensaios sobre São Paulo. São Paulo: Ed. Alameda, 2007.

${ }^{64}$ MOTTA, Márcia M. M. Direito à terra..., op. cit.

${ }^{65}$ Em 1598 foi edificada a igreja de S. Bento. BRUNO, Ernani Silva. História e tradições da cidade de São Paulo. 4 ed. São Paulo: Ed. Hucitec, 1991, v. 1, p. 109.

${ }^{66}$ BICALHO, Maria Fernanda, op. cit., p. 211-12. 
os religiosos laudêmios avultados e exorbitantes das propriedades que no dito lugar se tem vendido como foi a chacrinha a pé da ponte". Os religiosos do mosteiro, portanto, vinha sendo responsáveis por movimentar, no século XVIII, um mercado imobiliário de terras concedidas em mercê.

Em parte do rio Tamanduathey também fizeram um "pasto valado" que, originalmente, era apenas para manterem os gados do mosteiro, mas "pelo contrario se tem visto porque no dito cercado se fazem grande conveniência porque quem não tem dez réis por cada noite, não mete dentro o seu animal pelo pastar que por isto está disposto pelos mesmos padres". Uma lista com nove nomes informava os locadores de propriedades construídas pelos religiosos no Anhangabaú. A Câmara alegou que a mercê das terras aos padres era apenas para sua cerca e curral e não para fazerem patrimônio com prejuízo do bem comum. Em vista disto, determinava que se não interrompessem as cobranças iriam retomar as terras para "rocio e logradouro" da cidade. ${ }^{67}$

Memorialistas noticiam que a margem do rio Tamanduathey, se estendendo do Anhangabaú ao Bixiga, era usada por trabalhadores e animais das tropas para descanso, abastecimento de água e alimentação. $\mathrm{O}$ transporte em lombo de burro era obrigatoriamente intervalado por pausas para descanso especialmente nas planícies e baixadas desses rios históricos que se estendiam para freguesias articuladas com o núcleo central pelas pontes do Lavapés, porta de entrada para o caminho de Santos; pela ponte do Lorena, que dava direção para Pinheiros e campos do sul e pela ponte do Franca, rota para a planície do Brás, em direção ao Rio de Janeiro. ${ }^{68}$

$\mathrm{Na}$ época do governo de d. Luís de Sousa Botelho Mourão tem-se conhecimento de que havia apenas dois pousos para descanso entre a cidade e a Penha: o do Ferrão e Tatuapé ${ }^{69}$ Assim, a especulação da terra urbana visando atingir um mercado consumidor em expansão e de trabalhadores e animais em trânsito era bastante promissora, especialmente naquela conjuntura de estímulo à intensificação dos fluxos de tropas para o caminho do Mar. Enquanto nesta época de escassez de pontos de pouso na cidade os religioso do mosteiro cobravam $\$ 10$ rs de cada animal que pousasse em seus pastos, em 1816, quando o viajante SaintHilaire instalou-se na hospedaria do Bixiga, na mesma região foi-lhe cobrado apenas 1 vintém por noite e por cabeça de animal. ${ }^{70}$

\footnotetext{
${ }^{67}$ Atas da Câmara, v. XV, 1767, p. 262-264.

${ }^{68}$ BRUNO, Ernani, op. cit., p. 201-2.

${ }^{69}$ Idem, p. 312.

${ }^{70}$ SAINT-HILAIRE, Auguste. Viagem à província de S. Paulo. Trad. de Regina Regis Junqueira. São Paulo: P/B; Edusp; Ed. Itatiaia, 1976, p. 121.
} 
Os motivos de conflitos entre duas instituições do Império, como a câmara e o mosteiro beneditino, não se restringiam a transferência de atividades de uma a outra, como sugeriu Nuno Gonçalo para os casos de Setúbal e Évora, ou a rituais públicos, conforme o valor do Antigo Regime português de visualização pública das hierarquias. ${ }^{71}$ No caso dos beneditinos, na conjuntura de incentivo ao comércio externo da capitania, com consequente impacto nos trânsitos mercantis pela cidade, a concorrência com os poderes municipais dizia respeito à rentabilização de seu patrimônio fundiário, situado num entrocamento das principais rotas de comércio inter-regional.

A administração dos baldios foi, em Portugal, uma das principais atividades econômicas exercidas pelas confrarias. ${ }^{72}$ Nas cidades da América portuguesa, essa tradição traduziu-se no uso de áreas concedidas em "graciosa mercê", mas que os estímulos à exteriorização da economia da capitania do período e a geografia da cidade tenderam a constituir em meio de especulação.

As confrarias tinham um elevado potencial de conflitualidade ${ }^{73}$ devido a sua proximidade com o poder político e econômico local, pois em geral representavam membros de famílias influentes. Estas instituições rivalizavam com a câmara tanto para defender interesses próprios como os de um patrono ou membro leigo. Com isto dividiam as próprias elites locais.

Ainda no século XIX, com o fim das sesmarias em 1822 e a consagração do direito pleno de propriedade com a Constituição de 1824, a câmara metia-se em conflitos com estas instituições religiosas, com a intenção de assegurar as tradicionais áreas de servidão pública que faziam parte dos bens comuns do conselho, diante das ações individualizantes avalizadas por estas instituições religiosas. As mudanças ocorridas na legislação do Brasil independente também contribuíam para tensionar ainda mais a ocupação das terras na cidade.

Para justificar a colocação de portão com fechadura, privando os moradores da Luz da "regalia" de uma "aguada" e "antiquíssima posse", o capitão Francisco Antonio de Miranda apresentou às autoridades municipais uma carta escrita pelas recolhidas do convento dessa localidade, a qual dizia que sendo a casa muito obrigada a ele, capitão, "pelo muito que [as] favorece", permitia-lhe fechar a dita área.

Há muito as recolhidas da Luz desejavam fechar uma área próxima ao convento, pois um outro capitão, José Rodriguez Velloso de Oliveira, que fora almotacé da câmara em 1817, representando os moradores locais, no ano de 1826, havia

\footnotetext{
${ }^{71}$ MONTEIRO, Nuno Gonçalo, op. cit., p. 142.

${ }^{72}$ Idem, p. 57.

${ }^{73}$ Idem, p. 136.
} 
solicitado à Câmara vistoria na área, para assegurar sua condição de servidão pública. Na realidade, segundo as recolhidas, a área havia sido mantida aberta, ou seja "o vão na parede (...) e muro do cercado (...) o portão, e a casa mais vizinha delle foi por benefício [do capitão Francisco Antonio Miranda] afim de sua mais fácil serventia da água ou fonte que se acha dentro do pasto ou cercado desse recolhimento" ${ }^{74}$ Por outro lado, a ação do capitão Rodrigues Velloso mostra o quanto as elites locais não eram compactas e nem houve uma transição retilínea de uma moral de bem comum própria do século XVIII para a liberal do século XIX.

As confrarias eram elitistas, ${ }^{75}$ dependiam de favorecimentos e, para tanto, necessitavam zelar pela proximidade e patrocínio dos membros das elites locais. Aderir a um lado significava opor-se a outro. Como instituição religiosa, possivelmente fosse-lhes facilitada a concessão de terras na cidade para uso ou em graciosa mercê. Essas concessões, oriundas de uma moral régia tradicional persistente ainda nas primeiras décadas do século XIX, tornavam-se moeda de troca nas relações com membros da elite local, o que entrava em choque com a noção de bens comuns do conselho e, portanto, com a própria população da localidade que fazia uso destas áreas de domínio público. Não foi o caso dos beneditinos, mas os franciscanos fizeram uso das transformações na legislação do Brasil que asseguravam o direito pleno de propriedade desde a Constituição de 1824 para defenderem seu patrimônio particular e enfrentarem as alterações que o sítio da cidade vinha sofrendo.

A disputa entre a câmara e a ordem deu-se em torno do terreno anexo ao convento dos religiosos franciscanos, edifício tomado para a instalação do curso jurídico, em 1827. A câmara recorreu inclusive ao príncipe regente para garantir este terreno, obtendo como resposta que deveria "usar para esse fim dos meios marcados na lei ou entrar em alguma convenção com os religiosos, o que [parecia] ser mais prudente". ${ }^{76}$ De fato, a câmara recorreu à justiça contra os franciscanos, visando assegurar o que considerava um bem do conselho, invocando antigas prerrogativas de senhorio e posse e, ao mesmo tempo, argumentando que o direito de propriedade era incompatível com o instituto dos religiosos e que haviam abandonado o terreno quando cederam o convento. A justiça, contudo, deu ganho de causa aos religiosos,${ }^{77}$ firmando o princípio de propriedade ante a dogmática tradicional dos bens fundiários da câmara.

\footnotetext{
74 Papéis avulsos, v. 2, 06/02/1826.

75 Idem.

${ }^{76}$ Papéis avulsos, v. 32, 1830, p. 26.

77 Autos-cíveis. Arquivo do Estado de São Paulo, ordem 3.363, cx. 78, maço 2.466, 1834.
} 
O que chama atenção entre os dois casos envolvendo ordens religiosas e câmara é que, quando houve a presença de um juiz, no caso do conflito com os franciscanos, a argumentação de ambos os lados foi modificada, fundamentandose na nova legislação. Isto leva a pensar que um argumento pode às vezes dizer menos respeito à absorção de novos valores e mais à estratégia de ação, diante de conjuntura e agentes específicos.

\section{Disputas fundiárias na cidade}

A ambição por rentabilizar terrenos de seus sítios, aproveitando as oportunidades abertas pela expansão comercial da cidade, moveu tanto instituições como indivíduos. Documentos camarários e da justiça deixaram vestígios sobre o socorro que estes indivíduos e instituições buscavam nos meios legais para assegurar e comprovar a propriedade de domínios, originalmente concedidos apenas para moradia, trabalho e subsistência, ou seja, para uso.

$\mathrm{O}$ gesto de fazer das terras concedidas para uso em propriedades motivou muitas disputas pela terra na cidade, tanto entre senhores possuidores ${ }^{78}$ como destes com a câmara. Mesmo esta instituição perdendo certo poder de jurisdição sobre as terras da cidade, a partir do século XIX, com a implementação do imposto da Décima Urbana (alvará de 27 de junho de 1808), subordinado à Junta da Real Fazenda, e a transformação das câmaras municipais, em 1828, em corpos administrativos de poder restrito, os conflitos em torno da terra prosseguiram porque, na prática, foram conservados os direitos seculares sobre o aforamento, arrendamentos, aluguel de bens, venda e troca.

Desde a segunda metade do século XVIII, conforme vem sendo visto, as terras da cidade, "as de domínio camarário mais imediato", passaram a ser vistas como objeto de uso mercantil. Para este uso pleno havia a necessidade de comprovar a propriedade da terra ocupada, o que provocava contínuas fraudes aos direitos de propriedade da Câmara, ${ }^{79}$ especialmente à noção de bem comum do conselho que garantia, à coletividade local, o uso de certas áreas e seus recursos, como as fontes d'água, a extração de madeiras e o uso de pastagens para animais.

É rotineiro encontrar nos inventários de moradores da cidade o arrolamento de animais cavalares e muares, mas não o registro de terras e sítios ou moradas, o que reforça esta situação de uso efetivo das áreas comuns que faziam parte dos bens comuns

\footnotetext{
${ }^{78}$ Esta expressão, tomada de empréstimo das fontes de época, refere-se aos que em algum momento receberam uma concessão de ocupação de terra na cidade.

${ }^{79}$ GLEZER, Raquel, op. cit., p. 91-93.
} 
do conselho. A própria câmara lembrava aos munícipes que, "sendo (...) progressivo o aumento [da] cidade e cumprindo a esta câmara dar todas as providências a prol do bem público, este reclama por maior número de fontes, por uma praça de víveres (...) e do provir com espaço o Pateo [pátio de Palácio, na entrada da cidade de quem vinha do Rio de Janeiro] para o tráfico dos condutores e seus animais". ${ }^{80}$

Para enfrentar as implicações da movimentação mercantil no perímetro da cidade, a câmara polarizava-se entre a manutenção de sua autoridade, através da administração dos terrenos, de acordo com o direito colonial que incluía a noção de bem comum, e viabilizar o trânsito comercial.

$\mathrm{Na}$ ação de facilitar a mobilidade mercantil na cidade, teve de enfrentar ainda propósitos especulativos individuais, defender os direitos costumeiros e lidar com inúmeros conflitos oriundos da valorização do solo da cidade, pois os usos e concessões antigas formaram uma camada social indefinida de senhores possuidores de terras. Esta camada social protagonizou uma série de conflitos em torno da terra urbana que foram das injúrias verbais e agressões físicas nos sítios e roçados aos bancos da justiça, principalmente através das ações de Força Nova.

No que diz respeito às tendências especulativas em torno da terra da cidade, visando rentabilizar pastos para tirar proveito do aumento do trânsito de tropas de animais, o maior problema da câmara deu-se em torno das tradicionais áreas de servidão pública, patrimônio da instituição e voltadas para uso coletivo dos moradores. Muitos terrenos concedidos pela câmara em mercê, para uso como moradia e trabalho, e que, portanto, faziam parte de seus bens, ou seja, eram bens do conselho, situavam-se próximos, no caminho ou mesmo dentro de uma área de servidão pública, de forma que um sítio particular poderia ter em seus domínios uma área que, por gerações, era usada pela comunidade local. Ou seja, havia, em certos casos, a coincidência entre bens do conselho e bens comuns do conselho, conforme Raquel Glezer já havia sugerido.

Com a intensificação da atividade comercial na cidade, a tendência dos moradores dessas áreas foi a de fechá-las para uso particular, ou seja, instalando estalagens, pousos e hospedarias, com o intuito de rentabilizar um terreno que, na prática, era de antigo uso coletivo. Ou seja, o avanço de interesses individuais e especulativos entrou em aberto conflito com princípios do direito colonial, como a noção de uso comum.

Esta foi a situação vivida por d. Gertrudes, que possuía um sítio chamado Bixiga, situado entre o rio Anhangabaú de cima e que dava rancho e pouso a

${ }^{80}$ Papéis avulsos, v. 30, 09/09/1826. 
tropeiros. A câmara embargou-lhe uma obra de construção de um portão na área, em defesa do direito colonial do "bem comum", alegando, como no caso das recolhidas da Luz, que tal obra iria "privar a livre transitação a que está o público presentemente de posse para hirem buscar agoa e o mais que lhes he mister". Na sua defesa, a senhora alegou "que foi necessário fazer-se huma passagem para entrarem os tropeiros e mais pessoas que ião negociar com eles, independente de se abrir a porteira, e foi quando por esta ocasião foram se utilizando alguns pretos da entrada para irem apanhar lenha, água ou outras coisas, procurando sempre ocasiões de não serem vistos". Considerava ainda que a cidade tinha muitos matos em seu rocio onde o povo podia tirar lenha, sem necessidade de que o pasto de seu sítio ficasse aberto para esse fim. ${ }^{81}$

O direito de propriedade previsto na Constituição de 1824 tornou-se argumento invocado pelos que cercavam áreas de servidão pública próximas ou dentro dos terrenos onde residiam como advertiu um fiscal da Penha e São Miguel. ${ }^{82}$ José Rodrigues da Silveira foi um dos que empregou este direito, contra o juiz de paz, que mandara um escravo cortar lenha em suas terras. Rodrigues alegou que o juiz de paz calcara "aos pés o direito de propriedade que hé garantido ao cidadão em toda a sua plenitude pelo parágrafo 22, artigo 179 da constituição". O juiz respondeu que "não [existia] propriedade particular, que tudo [era] público", ${ }^{83}$ parecendo com este parecer endossar o direito colonial da câmara.

Levando-se em consideração os múltiplos contextos de uma circunstância histórica, ${ }^{84}$ este caso envolvendo José Rodrigues e um juiz de paz se distingue daquele dos fransciscanos. Naquele, os religiosos recorriam ao juiz com o argumento da legislação nova que deu-lhes ganho de causa. Neste, houve um conflito direto e pessoal entre um morador e um juiz, e este manuseou o direito costumeiro.

Em certas situações, a letra do novo regime, outorgada em 1824, passava a funcionar, nas mãos daqueles que cobiçavam o uso especulativo da terra da cidade, como um meio de justificar o avanço sobre as áreas de uso comum, o que em certa medida desafiava a autoridade que o conselho ainda conservava na administração das terras de seu termo e rossio.

O perímetro da cidade de São Paulo, mesmo de seu rossio, nas primeiras décadas do século XIX, ainda mantinha seu desenho colonial. A cidade, por

${ }_{81}^{81}$ Papéis avulsos, v. $25,1827$.

${ }^{82}$ Papéis avulsos, v. 42, 1832, p. 8

${ }^{83}$ Papéis avulsos, v. 44, 1832, p. 138.

${ }^{84}$ REVEL, Jacques. Microanálise e construção do social. In: REVEL, J. Jogos de escalas: a experiência da microanálise. Rio de Janeiro: Fundação Getúlio Vargas, 1998, p. 27. 
outro lado, e desde as duas últimas décadas do século XVIII, vivia não só uma realidade de expansão econômica, como demográfica ${ }^{85}$ Estima-se que, em 1776 , sua população englobava 3.820 almas, em 1794, havia atingido a cifra de 9.359, em 1815, perfazia um total de $25.313 .{ }^{86}$

Essa era uma boa combinação para ampliar os conflitos entre moradores, câmara e senhores possuidores de terras e para a tendência destes últimos de criminalizar as ações de negros pobres, livres ou escravos que recorriam ao direito de uso dos terrenos de servidão pública.

As tensões fundiárias também diziam respeito à complexa camada social de senhores e possuidores, com ou sem registro, que o direito colonial havia formado na cidade. Esta camada social via-se tanto diante da possibilidade de especulação com os terrenos como diante do risco constante de perder direitos de ocupação antigos, motivado pelo aumento da concorrência pela terra, como é possível acompanhar nos autos cíveis de Força Nova.

Nos autos pesquisados foi verificado que, na ausência do registro escrito, havia um conjunto de argumentos que justificavam a posse, como a palavra de alguém de prestígio e autoridade na localidade, como um oficial de patente, a memória e ocupação do antepassado, a concessão e o trabalho, lembrando que na lei de sesmarias uma das prerrogativas era a ocupação útil e produtiva. Contudo, desde 1822, esta lei não existia mais.

Quando Luciano Fernandes e sua mulher quiseram chamar para si as posses de um sítio, fizeram-lhe umas roças e mandaram uns animais que possuíam para este terreno. ${ }^{87} \mathrm{O}$ mesmo fez um preto forro, que se introduziu no sítio de d. Justa Maria de Oliveira e passou a fazer suas plantações. Só com o trabalho de roça conseguiu convencer até o governador da capitania de que era senhor do terreno ocupado, pois este concedeu-lhe direito de indenização pelos gados de d. Justa terem destruído suas plantações. ${ }^{88}$

Para os que ocupavam as terras, mais do que um título escrito, o que provava que ocupavam a terra era a exploração do solo, a realidade do cultivo e da construção de edificações para moradia e trabalho. A especulação dos terrenos da cidade, entre os anos 1765-1848, animou uma corrida aos tribunais para este tipo de justificativa para assegurar as posses, possivelmente motivada ainda pelos debates

\footnotetext{
${ }^{85}$ MARCÍLIO, Maria Luisa, op. cit.; BLAJ, Ilana, op. cit.; MOURA, Denise A. S., op. cit.; BORREGO, Maria Aparecida M., op. cit e TORRÃO FILHO, Amílcar, op. cit.

${ }^{86}$ QUEIROZ, Suely Robles Reis. São Paulo. Madrid: Editorial Mapfre, 1992, p. 126.

${ }^{87}$ Processo de embargo. Arquivo do Estado de São Paulo, ordem 3.672, cx. 239, proc. n. 3.972, 1819.

${ }^{88}$ Autos-cíveis. AESP, ordem 3.972, cx. 239, proc. n. 3.994, 1818. Na ocasião, o governador da capitania era d. Francisco de Assis Mascarenhas, conde de Palma.
} 
em torno da posterior lei de terras de 1850. Os conflitos fundiários na cidade de São Paulo diziam respeito ainda à multiplicidade de senhores proprietários formados pela ocupação sob o argumento do trabalho e pela informalização do direito colonial de concessão das terras, atributo do conselho, entre moradores da cidade.

Raphael Soares da Graça justificava morar num sítio por ele edificado em terras que foram de seu avô. Que junto ao sítio que morava era senhor e possuidor de "uns cultivados, aonde chamão Araçatuba", que pertenceram a três mulheres que o "passaram" a seu pai. Além da memória do antepassado, Raphael invocava, para justificar sua posse e senhorio, o seu trabalho de derrubar matas virgens, roçar, plantar e colher, sempre "mança e pacificamente". Até que a família Godinho resolveu fazer uma grande roçada nestas suas terras de Araçatuba.

Ao longo do processo, as testemunhas de defesa e acusação trouxeram informações que contribuem para pensar sobre atitudes que possivelmente foram comuns na estrutura fundiária das cidades coloniais na América portuguesa ${ }^{89} \mathrm{Os}$ réus demonstraram que originalmente os cultivados, dos quais Raphael se dizia senhor e possuidor eram de Roque Soares que, ao morrer, os deixou para seu filho que, ao falecer, os deixou em inventário para sua mulher, Martha Maria de Camargo. Esta concedeu a Domingos Dias "a mercê de nellas plantar", mas quando este morreu, suas filhas venderam estes cultivados para Antonio Soares, pai de Raphael.

Na realidade, Raphael havia comprado as terras de seu pai, por "hua dolbras", o que sugere a existência de um mercado familiar de terras que motivava Raphael a tentar provar na justiça sua condição de proprietário, em meio a uma retórica do direto colonial, pois invocava a memória dos antepassados e da mansa e pacífica posse.

A família Godinho, contudo, também comprou os mesmos cultivados, porém, da senhora original, Martha Maria de Camargo, e como Raphael já os ocupava como senhor e possuidor, surgiram os conflitos. Principalmente porque o pai de Raphael, Antonio Soares, chegou a reconhecer que havia comprado as terras de quem não as podia vender e as restituiu à família Godinho, firmando em papel e recebendo desta o valor que havia pago.

A carta de Antonio Soares dizia: "que de verdade e que de minha livre vontade entrego meus cultivados de terras a Ignácio Godinho Pais porque conheço que comprei inadvertidamente de Anna Conceição e de suas irmãs, filhas do falecido Domingos Dias pela quantia de $5 \$ 000$, porque venho na certeza destas que não

\footnotetext{
${ }^{89}$ No caso português, os conflitos de terras entre casas senhoriais e eclesiásticas com as câmaras foram comuns. As casas senhoriais exerciam poder absoluto sobre áreas que consideravam seus domínios, ocupando espaços incultos que confinavam com área do patrimônio concelhio. Cf. NETO, Margarida Sobral, op. cit., p. 158-163.
} 
podiam vender por serem estas terras pertencentes a D. Martha de Camargo por fazer favor a Domingos Dias (...) ficando as terras e o sitio Caraguatá ao Ignácio Godinho Paes e desse recebi o dinheiro que dei pelos mencionados cultivados (...) e assim entrego os ditos cultivados ao seu próprio dono".

Raphael Soares e as testemunhas a seu favor insistiram na tese de que seu pai escreveu tal documento coagido pela presença do capitão Salvador Pires de Oliveira Mendes, da companhia em que seu pai servia como soldado. Também invocaram o argumento de que as terras de Araçatuba não pertenciam a Martha Camargo, mas à sesmaria de José Novais Dias, e quando a família Godinho desentendeu-se com este, pela mesma disputa das terras, recorreu ao vigário-mor da freguesia, a quem o dito Novais muito respeitava. ${ }^{90}$

Todas essas questões permitem pensar que uma concessão em sesmaria desdobrava-se em várias outras mercês informais, extra institucionais, pois saíam do domínio da câmara e envolviam apenas os moradores locais, de senhores de patente, com poder e prestígio, aos mais pobres, soldados e trabalhadores de seus próprios cultivados, muitas vezes sem escravos. Muitos senhores possuidores poderiam surgir para um mesmo domínio ou dentro de um terreno poderiam existir várias doações, o que ocasionava conflitos quando a terra era vendida.

O capitão Joaquim Manuel Gomes enfrentou esse problema, porque adquiriu um sítio de terras a Camilo José de Almeida. Neste sítio viviam arranchados, "por favor e faculdade", o casal Antonio Barnabé Ribeiro e Francisca Pedroza Moraes. Diante da recusa em saírem das terras, o capitão recorreu à justiça para disputar esse pedaço do sítio ocupado. Terminou sem esse pedaço, denominado Monjolinho, porque o casal conseguiu provar, com "titulo de doação que lhes fizeram Pedro José de Siqueira e sua mulher Francisca Luiza”, que essas terras foram cedidas a José Pinheiro, "para ali viver enquanto a sua vida irem toda a sua familia trabalhar e plantar como suas próprias" e este lhes passou o direto de uso. Assim, o casal não se via na obrigação de sair de terra que "legitimamente lhes pertence", argumentando ainda que se a aquisição do capitão Joaquim Manuel incluía as terras deles, eles "com isto nada [tinham]", porque o capitão é que fora inocente comprando terras que não pertenciam ao vendedor, mas sim à família dele, José Ribeiro. ${ }^{91}$

No mercado fundiário familiar e extra familiar que existia na cidade desde o século XVI, um dos principais fatores de conflito era esta sobreposição de mercês num mesmo terreno que fazia com que, na terra adquirida, às vezes, viesse junto

\footnotetext{
${ }^{90}$ Ação de Força Nova. Autos-civeis. AESP, ordem 3.399, cx. 114, maço 114, 1821.

${ }^{91}$ Sentença de apelação cível passada a favor de Francisca Pedroza de Moraes... AESP, ordem 3.407 , pasta $3.155,1839$.
} 
um outro senhorio, adquirido de outro senhor proprietário que não aquele que operava o negócio da venda imediatamente. Essa coincidência de senhorios nas conjunturas de negociação da terra ocasionava os conflitos fundiários.

As informalidades que surgiam do próprio direito colonial da concessão em mercê se defrontaram com outras esferas de autoridade que podem ser consideradas concorrentes às dos conselhos, como os vigários e senhores de patentes. ${ }^{92}$ Muitos dos conflitos ocasionados por mercês informais, antes de chegarem aos tribunais, passavam pelo crivo do vigário ou do potentado local, que se constituíam como autoridades concorrentes à da câmara, administradora original dos terrenos da cidade. Pode-se cogitar a hipótese de que, desde 1808, com a instauração de um imposto como a Décima Urbana, sob área municipal, mas da alçada da Junta da Real Fazenda, houve um fortalecimento das autoridades informais locais, representadas por alguém que conseguia agregar por fatores vários algum tipo de prestígio.

O enfraquecimento do poder legal da câmara, embora ainda conservasse direitos seculares, pode ter tido algum impacto sobre os moradores locais, especialmente entre aqueles que se envolviam com litígios de terra. Assim ocorreu com a tentativa de conciliação entre Maria Madalena e Dionízio Rodrigues da Silva, moradores no bairro da Cachoeira, distrito de Santa Ifigênia, que primeiro buscaram assistência do comandante do bairro para que houvesse acomodação dos seus desentendimentos de divisas de terreno. $\mathrm{O}$ acordo terminou rompido pela mulher de Dionizio o que os obrigou aos meios legais de conciliação com os seus títulos. ${ }^{93}$

Neste caso, novamente aparece um argumento que parece ter funcionado como um mecanismo informal de legitimação do senhorio e propriedade: o trabalho manso e pacífico na terra, por muitos anos e sem incômodo de vizinhos. Nos autos cíveis de questões fundiárias, em que os litigantes geralmente afirmam que possuem os títulos de propriedade, não há indicação de que fossem apresentados, mas o trabalho endossava a posse e propriedade.

Dionízio Rodrigues, do caso acima, chamou a posse das terras que disputava com Maria Madalena "trabalhando e disfrutando-as como se fossem suas". O tenente Pedro Gonçalves Meira foi mais além: reuniu alguns libertos e cativos, seus e de seu irmão, alguns instrumentos de trabalho e "tambor (...) para fazer espertos e alegrar os negros" e chamou para si a posse de terras já ocupadas na cidade.

A fama de um dos litigantes era de, juntamente com seus parentes, lavrar terras alheias, tendo, inclusive, "várias demandas de terra". Na solução desta contenda,

92 Sobre esta interessante questão da concorrência de poderes no município, cf. MONTEIRO, Nuno, op. cit. e NETO, Margarida Sobral, op. cit.

93 Autos cíveis. AESP, ordem 3.407, maço 3.163, 1826. 
antes dos tribunais, novamente tentou-se a conciliação através da interferência pessoal, recorrendo-se a um capitão da localidade. ${ }^{94}$

\section{Conclusão}

Este texto comunga da tese defendida há certo tempo, por uma vertente da historiografia sobre São Paulo, entre o século XVIII e início do XIX, de que a capitania e cidade de São Paulo não estavam fora de uma dinâmica mercantil. O viés escolhido para esta discussão foi o problema dos conflitos em torno da terra na cidade de São Paulo. Tanto a historiografia citada que se dedicou ao movimento mercantil na cidade e capitania de São Paulo, como pesquisas em andamento sobre este mesmo movimento na vila marítima de Santos, datado desde a segunda metade do século XVIII, trazem subsídios para se pensar sobre o quanto esta movimentação levou ao uso mais intensivo do perímetro urbano da cidade, via de acesso obrigatória para o porto de Santos.

De fato, nos documentos municipais e nas ações cíveis de Força Nova existem muitos vestígios de processos de ocupação ilegal de terras que tradicionalmente pertenciam aos bens do conselho, de terrenos costumeiramente utilizados coletivamente ou de um mercado de terras originalmente concedidas em mercê para uso e não para serem comercializadas.

Os problemas da terra nas cidades da América portuguesa e os conflitos em torno de seu acesso ainda merecem ser mais bem investigados. Estes são assuntos diretamente relacionados aos conselhos municipais. Através deles pode-se analisar como estas instituições reagiram aos poderes concorrentes, régios, de ordens religiosas e senhores possuidores que impuseram pressões contra a sua identidade e autoridade local.

Recebido: 28/10/2009 - Aprovado: 24/05/2010.

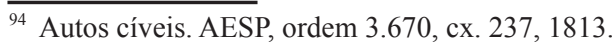

